\title{
Export hit "Vergangenheitsbewältigung". Germany and European integration as a model for Korea and East Asia?
}

Ton Nijhuis

\author{
Correspondence: a.j.j.nijhuis@uva.nl \\ Universiteit van Amsterdam, \\ Duitsland Instituut Amsterdam, \\ Kloveniersburgwal 48, 1012 CX \\ Amsterdam, Netherlands
}

\begin{abstract}
The process of coming to terms with the history of two dictatorships against the backdrop of the country's partition and reunification makes Germany a special extraordinary case and a pioneer for other states as well. The German Vergangenheitsbewältigung (coming to terms with the past), has been an inspiration for other EU member states and for the process of European integration. Also, on an European level, history is an important source of identity formation. Can the German Vergangenheitsbewältigung, German Unification, and European Integration be a source of inspiration for Korea and East Asia?
\end{abstract}

Keywords: German history, Memory studies, German political culture, Vergangenheitsbewältigung

\section{Zusammenfassung}

Die Bewältigung von zwei Diktaturen gegen den Hintergrund von Teilung und Wiedervereinigung hat Deutschland zu einem einzigartigen Fall gemacht, und zum Beispiel für andere Länder. Die deutsche Vergangenheitsbewältigung ist eine Inspirationsquelle für andere europäische Mitgliedstaaten gewesen und auch für die EU und den Prozess der europäischen Integration. Auch auf europäische Ebene ist Geschichte eine wichtige Quelle für Identitätsbildung.

Kann die deutsche Vergangenheitsbewältigung, deutsche Wiedervereinigung und europäische Integration eine Inspirationsquelle für Korea und Südostasien?

\section{Introduction: Germany's Vergangenheitsbewältigung}

"Made in Germany" stands for quality. Germany is not only a large exporter of technologically advanced goods and cars. The way in which the country deals with its past is also being perceived with a certain admiration and, at times, with astonishment in the rest of the world. Nobody can emulate the Germans' Holocaust - nor their overcoming of it, the well-known publicist Henryk M. Broder once mockingly remarked. The Hungarian author Péter Esterházy described the Germans as 'Weltmeister der Vergangenheitsbewältigung' (world champions in coming to terms with the past).

Coming to terms with the history of two dictatorships against the backdrop of the country's partition and reunification makes Germany a special case anda pioneer for other states as well. As a result of its need to cope not only with National Socialism,

(C) 2016 Nijhuis. Open Access This article is distributed under the terms of the Creative Commons Attribution 4.0 International License (http://creativecommons.org/licenses/by/4.0/), which permits unrestricted use, distribution, and reproduction in any medium, provided you give appropriate credit to the original author(s) and the source, provide a link to the Creative Commons license, and indicate if changes were made. 
but also with the communist dictatorship of the German Democratic Republic (GDR), the Federal Republic of Germany (FRG) has developed considerable expertise in dealing with the past. ${ }^{1}$ For this reason, international delegations regularly visit Berlin to find out how Germany copes with its past. Passing on this knowledge is also part of the task that Germany, as a civil power, has bestowed upon itself. In the words of the German historian Jan-Holger Kirsch: in its foreign policy Germany acts as an international aid worker in the matter of Vergangenheitsbewältigung. ${ }^{2}$

\section{Germany's return to the western community of states}

After the Second World War, the FRG not only had to create a new identity for itself, it also had to develop a new political culture. Furthermore, it was important to ensure that the new country, which was simultaneously the legacy of the Nazi Third Reich, would be welcomed back into the community of nation-states. When the Second World War ended, Germany was a devastated, morally bankrupt country that was hated and deemed untrustworthy. Germany, therefore, focussed on becoming part of the international stage as an alliance partner again as quickly as possible. Apart from its acceptance into NATO, which was essential for the existential security of the FRG during the Cold War, the process of European integration was undoubtedly the main instrument for ensuring renewed acceptance by its neighbouring countries. Germany always had to dig deep into its pockets to maintain the European integration process. On a national level, it encountered criticism in the process, becauseunlike other countries, Germany was blamed for doing too little to represent its national interests. Even before the unification, a small but influential circle of observers of German foreign policy deplored the lack of Machtpolitik (power politics) in the Federal Republic. ${ }^{3}$ However, this criticism fails to take into account an important aspect That is to say, by following this course, Germany managed to transform itself from a hated, untrustworthy country into a respected neighbour and partner in international organisations within a very short space of time. If the country had continued to campaign for nationalist causes and if it had enabled national interests to take precedence, Germany would never have been able to gain the trust of other countries on the European continent so quickly, and it would never have been accepted so readily as an alliance partner. ${ }^{4}$

\section{A limited political purge}

All the same, the critical approach to its own past was not given priority after the war, and denazification after the Second World War was anything but thorough and effective. Although the process of denazification in the FRG differed greatly from the GDR, it tended in both cases to be hesitant and inadequate. Rather than scrupulously pursuing denazification in Germany, injustice was tracked down on a selective basis.

Other matters took priority. In international politics, the Cold War started immediately after the Second World War. Anti-communism was at least as important as antiNazism. In home affairs, and I restrict myself here to the BRD, the country had to quickly ensure the establishment of new institutions and economic growth after the war in order to create stability and to integrate millions of new fellow-citizens, such as displaced persons. Here, too, justice versus realpolitik is the eternal dilemma.

The country needed every single skilled worker possible to ensure Germany's rapid reconstruction. A maximum number of people had to be integrated as quickly as 
possible, at whatever prize. Rigorous denazification would have been detrimental to the reconstruction and would have made it more difficult to integrate the new citizens in the new political order. Federal Chancellor Konrad Adenauer's right-hand man for example, Hans Globke, had a Nazi past. Adenauer defended his often very forgiving treatment of such employees by stating that he could hardly be expected to choose another populace.

Remaining silent about what had happened was at first the most commonly applied strategy in order to pick up the thread again and to rebuild the country. Remaining silent helped society to become integrated quickly.

At the same time, however, the FRG accepted in its foreign policy the responsibility for the crimes committed by the Hitler regime; the country made reparation payments, and it made no attempt to negate or trivialise the crimes.

\section{Coming to terms with the past}

When we talk about "Vergangenheitsbewältigung", we must distinguish between at least three different levels. The first level involves taking legal action and condemning those who committed the crimes. The second level embraces financial reparation. The recognition of guilt must also be accompanied by compensation. And, finally, the critical self-questioning of society and the acceptance of responsibility.

If, then, we wish to assess the success of Vergangenheitsbewältigung, we must ask which aspects should be used to measure it, and how we wish to execute it: perhaps based on the extent to which the guilty must answer to the court, or the amount of compensation paid to the victims? Or based on the changes in political, cultural and social conditions and the development of stable democratic institutions? Or maybe to the extent of reconciliation between perpetrators and victims?

After the Second World War, the legal aspects of coming to terms with the past were relatively simple because, as a result of the moral bankruptcy, a pretty clear differentiation could be made between good and evil, right and wrong. The reason why denazification was not pursued scrupulously, as mentioned above, is that it would have seriously obstructed reconstruction. The emphasis was placed on re-educating by means of political education; developing a democratic political culture and enabling society to have a completely different cultural focus.

The legal aspects of Vergangenheitsbewältigung were more complicated, following the reunification of the two German states in 1990. The GDR acceded to the Federal Republic of Germany. It was a union under West German leadership and based on federal republican principles. And, in contrast to the period after the Second World War, when the perpetrators lived in Germany and most of the victims beyond the German borders and the country as a whole had to assume responsibility for the crimes, this time the perpetrators and victims lived side by side. Consequently, only one section of society had a dictatorial past that had to be overcome. This resulted in integration problems and completely different dynamics. A contrast between east and west inevitably and instantaneously arose; an extremely asymmetrical relationship that many people from the former GDR would come to experience as a form of colonisation. Although it was evident that communist East Germany was an unjust state, many people consider the prosecution and condemnation of leading individuals in the GDR to be a form of victor's justice. For this reason, dealing with the past had not simply 
the 'cleansing' effect it had after the Second World War, it also led to a 'feeling of us against them' on the eastern German side. In this sense, coming to terms with the past also proved to be an obstacle to integrating the two parts of Germany and the eastern German population into the FRG.

This was compounded by the fact that, in contrast to the period directly after the Second World War, the past was dealt with swiftly and most thoroughly. There was an immediate boom in historical studies on the GDR, and two parliamentary inquiries were conducted. Rarely has the recent history of a country been investigated so intensively as that of the GDR following unification.

This thoroughness was also a result of the experience gained by historians in dealing with the Nazi past. Knowing that it took some time after the Second World War before the process of confronting the past was initiated, this time the intention was to get started immediately and to relentlessly expose the injustices committed, instead of doing it half-heartedly. In the process of coming to terms with the SED dictatorship, those responsible wanted to make sure from the outset that the mistakes and deficits of dealing with the Nazi past would not be repeated. For many West Germans, Vergangenheitsbewältigung after 1945 was the road to recovery; this was not the case, however, for many eastern Germans post-1990. They saw it as a diktat of coming to terms with the past, rather than as coming to terms with the dictatorship.

\section{Vergangenheitsbewältigung and integration}

It is, therefore, not always the case that dealing thoroughly with the past has a positive effect on integration. From the perspective of integration, it may sometimes be better to not (yet) address the issue of the past in great detail as, for example, in Poland, where a thick line was drawn under the past. Or in Spain, where the subject of dictatorship was not addressed for a long time out of fear that fuelling old conflicts would jeopardise the integration of Spanish society. What is known as the 'unspoken pact' (pacto silencio) prevailed in these cases. History and the existence of a common culture may have an integrating effect, but it may also have a disintegrating effect. ${ }^{5}$

This 'reconciliation by silence,' however, is always fragile and in the end it is often not sustainable. Old questions and responsibilities cannot be ignored forever as Poland and Spain have proven. The question of whether or not to address difficult conflicts in the past is also a question of timing. The 'reconciliation by silence' cannot be more than a mid-term solution. In the end, in order to reach real and sustainable integration one has to come terms with the past.

By the way: after the Second World War, most people in Germany also wanted to forget about the Nazi-period. In that sense, we could say the Vergangenheitsbewältigung really started in the late sixties and seventies. Although at first it had an unsettling effect on feelings of national identity, in the end, it made the national integration stronger and more robust.

In regard to the integration of new groups into society, strictly speaking, the same threefold division can be made as for the Vergangenheitsbewältigung.

Obviously, first of all the legal requirements: do individuals have the same legal and political rights in order to participate in society as a full citizens?

Then there are the economic conditions. It is not possible to speak of a successful integration without having equal opportunities on the labour market. And finally, as 
usual, the most difficult aspect: cultural integration, which I would here like to define in very broad terms of participation in various areas of social life. A lack of participation can either be the result of a lack of will, or a lack of possibility to participate.

\section{Economic and cultural integration}

How do legal, economic and cultural integration interact with each other?

These forms of integration are closely linked. Cultural integration is impossible if legal and economic integration has not been achieved.

If we look at the integration of the two German states, it is evident that, at the purely formal level, there were equal legal and political rights immediately after unification. In practice, however, eastern German citizens initially found it difficult to pursue a career in politics, or to be appointed to high public offices, although currently both the Federal Chancellor, Angela Merkel, and the Federal President, Joachim Gauck, are East Germans. The difference in experience, relevant training, the lack of networks, the different linguistics, different style and culture proved to be obstacles that withheld eastern German citizens from having equal opportunities. And yet, the constitutional, legal dimension of integration must be regarded as a success, as must the establishment of political institutions. Although, at the beginning, there was only a slight acceptance of democratic values in the former GDR, which still continues to be slightly below the level of acceptance in the west to this day and thereby weakening the legitimacy of democracy, the political institutions mastered this trial of strength extremely well. A comparison with Korea immediately comes to mind. If the North Korean regime was to collapse and both Koreas would be reunited, this trial of strength would occur in a much more severe form, for the mere reason that North Korea is comparatively larger than the GDR. South Korea has twice as many inhabitants as North Korea, whereas the FRG had four times as many inhabitants as the GDR. So the burden that South Korea would have to carry is twice as heavy (1:2 vs 1:4).

Besides, North Korea is much poorer than the GDR, so the costs of economic integration will be much higher than in Germany. Political integration will also be much more difficult because North Korea is almost completely isolated from the rest of the world, whereas the East Germans all watched West-German television and were quite well aware of what was going on in the Federal Republic.

German Unification would not have been possible without European integration. And European Integration would not have been possible without the Franco-German reconciliation and the German Vergangenheitsbewältigung. In East Asia, the politics of reconciling the main players (China, Japan and Korea) have been less convincing and successful, also because of the unwillingness to accept historical guilt and responsibility, especially by Japan. The geopolitical tensions in the East Asian area make a Korean unification much more difficult than the German Unification after the Fall of the Berlin Wall. But the German case also shows that one should never give up on the prospect of unification. ${ }^{6}$

The economic development of the new eastern states of Germany was more complicated. The East German economy had to be integrated into the liberal market structures of the West, but it was unable to keep pace with competition from the West. This led to the closure of many plants and companies, and unemployment increased sharply. This, in turn, resulted in strong disappointment and a certain longing for the 
old GDR, where at least unemployment did not exist. The enormous financial efforts to integrate the eastern German territories infrastructurally and economically appeared to be largely ineffective at first. In a period of 25 years, some 2000 billion euros were transferred from west to east. Unemployment rates remained for a long time substantially higher and wages lower. In spite of these differences, economic integration now seems to be making good progress.

In the past 25 years, cultural integration has led to a considerable convergence of life in the old and the new federal states. Although the cultural differences between the east and the west remain the subject of much debate in Germany, it is actually no longer possible to discern any major fundamental differences with regard to culture, the enjoyment of freedom, the level of prosperity, consumer behaviour, media use, leisure activities and forms of relationship. The differences are only in degree, and their significance are magnified in the public sphere. If the differences between east and west in the Federal Republic of Germany are compared with differences in other European countries, they are not unusual or extremely large.

For eastern Germans, national sentiment played an important role in becoming integrated into an enlarged FRG. During the revolution, the people chanted "Wir sind ein Volk" (We are one people), expressing their desire to live together in one country.

The western part of Germany saw unification much less as a national undertaking. After the Second World War, the Federal Republic of Germany had virtually given up on thinking in national terms. Terms such as nationalism and national interests had a negative connotation. People became accustomed to speaking of European concepts, of European interests. For Germany, Europe was the Ersatz nation for the discredited nation-state.

The desire to be reunified did not prevent that in both parts of Germany there existed a certain longing for the days before reunification. West Germans, felt a longing for the calm and affluent Bonn Republic; East Germans, felt a longing for the old GDR, where unemployment was non-existent and where they did not feel like second class citizens. This and also, linked to this, the public condemnation of the GDR past, has enabled nostalgia to grow.

The fact that, particularly, the right-wing populist Pegida movement receives approval from the new eastern states of Germany is certainly linked to this longing for old, familiar relations.

\section{Historical memory and European integration}

Yet, it is precisely that by renouncing nationalism, West German Vergangenheitsbewältigung could lay the foundations for European integration. The European project was chosen in order to prevent an even bigger war from breaking out on the European continent. The Holocaust binds the European nations to this project. There is a political consensus about the identity-forming strength of historical awareness, which focuses fully on the victims.

The European Parliament assumes that the memories of Europe's tragic past must be kept alive in order to honour the victims, condemn the perpetrators and lay the foundations for reconciliation based on truth and remembrance. In a resolution, the Parliament reconfirms its united stand against all totalitarian rule from whatever ideological background. By a large majority, the European Parliament called for the 
proclamation of 23 August as a Europe-wide Day of Remembrance for the victims of all totalitarian regimes. This day is to be "commemorated with dignity and impartiality." A European Network Remembrance and Solidarity was created in 2005 . $^{\text {? }}$

Just as remembrance is used in the reconstruction of nations, or in the search for a national past, at the European level, keeping alive the memory of injustice and of the victims constitutes the foundation of European unity. Thus, cultural integration in Europe takes places via a shared critical perspective of the past.

Based on this critical perspective of the past and on criticism of dictatorships, undemocratic structures and nationalism, Europe has developed a common system of values. Freedom, democracy, human rights and social justice are central to this system of values.

This is also the reason why transnational history policy and remembrance policy are considered common European tasks. Even though it is not one of the official criteria for accession to the EU, by keeping in mind the critical approach to Nazi dictatorship, it is possible to talk of a kind of European standard. It demonstrates, as it were, that the European system of values has been embraced.

In short, just as the conditions for Germany to become reintegrated into Europe required a critical and relentless approach to deal with its own past, this successful form of Vergangenheitsbewältigung acts as a model for Europe as a whole. Or as the German Chancellor Angela Merkel stated during a visit in March 2015 to Japan: "Coming to terms with our own past was thus an essential factor in making reconciliation possible. Of course reconciliation always needs two sides. In our case, France, for instance, was willing to extend a hand of friendship to Germany after the Second World War. Basically the European Union we have today is the product of this reconciliation".

Just as there can be no reconciliation without remembrance, Europe will not truly 'become one' if it is incapable of developing a shared perspective of its history. A perspective in which a clear position is taken against Nazism, Stalinism, fascism and communist regimes. And of naming their crimes.

Vergangenheitsbewältigung has allowed room for the voice of the persecuted, drawing public notice to the everyday life of repression. It has established a culture of remembrance that is built on a critical scrutiny of the past rather than on an affirmation of traditions. To some extent, memories have surpassed progress as the cultural standard of reference in the western world.

The famous Spanish writer Jorge Semprún stated in 2004 following EU enlargement involving 10 new Member States: "One of the most effective means of preparing the way for the future of a united Europe, or rather a reunited Europe, is to share our past, to unite our memories, our hitherto separate recollections." The recent accession of ten new countries from Central and Eastern Europe can only work culturally and existentially when we are able to share our memories, including those of the other Europe, the Europe that was caught up in Soviet totalitarianism. ${ }^{9}$

Therefore, memories are the cultural foundation of European integration and Vergangenheitsbewältigung is the gateway to a Europe of values.

The European culture of remembrance does not wish to be exclusive, as nationalism always was, but rather inclusive. It seeks to integrate.

In the nineteenth century and the first half of the twentieth century, the nation-states primarily saw each other as competitors and strategic adversaries. One nation-state's 
gain was tantamount to another's loss. But now the countries mainly consider themselves to be alliance partners, where one partner's advantage benefits the whole entity. It is no longer a matter of carving up the cake, but of expanding it.

In the classic nation-states of the last two centuries, the population of a country was in effect always integrated into the country by way of tradition, the church, social class, the village and region. Nowadays, this is increasingly no longer the case in European countries. In an individualised society, integration does not take place via the ethnic, religious or social economic collective, but via shared cultures, values and ways of life. What we call the 'symbolic society' is also noticeable at the European level.

The renunciation of nationalism and commitments to European values have led to a longer period of peace, stability and reconciliation. This is also the reason why the EU received the Nobel Peace Prize.

This development has not only ensured peace and stability, it also prepares countries for a globalised world. In particular, renouncing the menacing forces of nationalism, looking outwards and being open to cooperation with other countries on the basis of shared values - it is this stance that belongs to a completely interdependent world. This transition must also occur at the global level so that countries no longer view each other as competitors or strategic adversaries, but as partners who, together, can achieve more than any country can ever hope to achieve on its own.

\section{Conclusion}

The fact that Europe - after centuries of warfare and the most heinous crimes - has managed to evolve into a peaceful continent, where mutual trust between the peoples has developed again, could make it a role model for the East Asian region. It goes without saying that the prerequisite for the European project was that Germany pleaded guilty after the war and dealt relentlessly with its past. Other countries have subsequently also examined their own past critically. This self-critical stance is essential for opening up to others.

However, I cannot yet imagine that Japan, for example, takes responsibility for its past crimes in the same way, which is an obstacle to reconciliation and integration. There is no shared historical memory between China, Japan and Korea. And as long as this shared memory fails, tensions instead of integration will characterize the region. Moreover, in Europe integration was made possible by 1) a common enemy during the Cold War, 2) the more or less balance of power between the West European states and 3) the role of the United States. In East Asia all three elements lack: 1) there is no common threatening enemy, 2) China, Japan and Korea are not comparable large states and economies, and 3) there is no external integrator, comparable to the United States.

One final qualifying remark: the description I have given of the development of the German Vergangenheitsbewältigung, culminating in a shared culture of remembrance, closely resembles a success story. In practice, however, it was a long, painstaking and painful battle.

Germany was not immediately an exemplary democracy after the war. Until the sixties the Federal Republic had a more or less authoritarian political culture. ${ }^{10}$ Civic education and Vergangenheitsbewältigung are a slow processes. But they are worthwhile. Integration and cooperation have triumphed over nationalism and fighting. 
At present, however, the financial crisis, the economic decline and the refugee crisis have led to a resurgence of nationalism, with right-wing extremism and right-wing populism gaining more ground. Old stereotypes that countries had of each other are suddenly resurging. The achievements of integration are, therefore, never finite; a reversion is always possible. European integration is not a natural and irreversible process. It is, therefore, of lasting interest to continue pursuing European integration on the basis of these shared values and culture. One means of achieving this is critical Vergangenheitsbewältigung.

\section{Endnotes}

${ }^{1}$ This is not to say that an enlightened public is necessarily the result. The number of research projects, monuments and commemoration days reveals only little about the political culture which, in the East, for example, regardless of all enlightenment, is marked by authoritarian traditions of thought, which may explain the relative success of the right-wing extremist NPD (National Democratic Party of Germany), the rightwing populist AfD (Alternative for Germany) party and Germany's anti-Islam Pegida movement.

${ }^{2}$ Jan-Holger Kirsch, "Befreiung" und/oder "Niederlage"? Zur Konfliktgeschichte des deutschen Gedenkens an Nationalsozialismus und Zweiten Weltkrieg, in: Burkhard Asmuss/Kay Kufeke/Philipp Springer (Hg.), 1945 - Der Krieg und seine Folgen. Kriegsende und Erinnerungspolitik in Deutschland, Berlin/Bönen 2005, S. 60-71, p.67.

${ }^{3}$ The most important academic critics were professor Arnulf Baring, professor Gregor Schöllgen, professor Michael Stürmer, professor Christian Hacke and professor Hans-Peter Schwarz. Hans-Peter Schwarz published in 1985 his book Die gezähmten Deutschen. Von der Machtsbesessenheit zur Machtvergessenheit. (The tamed Germans: From obsession with power to forget about power).

${ }^{4}$ Ton Nijhuis, 'Historical Memory and the Plea for a National Interests Based German Foreign Policy’, in: Czech Sociological Review VI (2/1998), pp. 205-218.

5ürgen Kocka, 'Geschichte als Aufklärung?', in: Jörn Rüsen, Eberhard Lämmert, Peter Glotz (ed.), Die Zukunft der Aufklärung, Frankfurt am Main 1988, p 96.

${ }^{6}$ See also: Conrad Rein, 'An East German Perspective on Korean Reunification', in Strategic Analysis 39, 2015, 535-540.

${ }^{7}$ http://www.enrs.eu/

${ }^{8}$ https://www.bundesregierung.de/Content/EN/Reiseberichte/2015/2015-03-09-merkel-japan_en.html

${ }^{9}$ http://www.buchenwald.de/en/1251/\#sthash.0e9wpMog.dpuf

${ }^{10}$ See e.g. Russell Dalton, Politics in Germany: the online edition, chapter 4 Changing Political Cultures: http://www.socsci.uci.edu/ rdalton/germany/ch4/chap4.htm

Abbreviations

AfD: Alternative for Germany; EU: European Union; FRG: Federal Republic of Germany; GDR: German Democratic Republic; NPD: National Democratic Party of Germany.

Competing interests

The author declares that he has no competing interests.

Received: 4 January 2016 Accepted: 14 March 2016

Published online: 25 May 2016 